\title{
ULTRASONOGRAPHY FEATURES AND SCREENING OF OVARIAN MASSES IN REPRODUCTIVE-AGE WOMEN
}

\author{
Spiridonova NV, Demura AA $₫$, Katyushina VO
}

Samara State Medical University, Samara, Russia

\begin{abstract}
Ovarian neoplasms can develop at any age, carry a high risk for malignant transformation, reduce the reproductive potential of a woman and are an indication for surgery. The search for optimal screening algorithms for ovarian tumors is still ongoing. The aim of this study was to evaluate the prognostic efficacy of ultrasonography (US) features in differentiating between benign, malignant and borderline tumors in reproductive-age women. We examined 168 reproductive-age women with ovarian masses who underwent surgery in 2012-2015 and compared the results of histopathological examinations with pulsed-Doppler US findings. We did not establish a correlation between the size/volume of the tumor and their morphological structure. We identified the echotexture characteristics associated with malignancy, including the presence of a solid component $(p<0.001)$; septations $(p=0.029)$ and projections on the internal surface of the tumor capsule $(p<0.001)$; moderate or significant buildup of free fluid in the small pelvis $(p=0.007)$, and the nodular surface of the tumor capsule $(p=0.008)$. Solid ovarian masses were at increased (31.69-fold) risk of transformation into malignant or borderline tumors, whereas for a mixed (cystic and solid) type the risk of such transformation increased 3.46-fold. We also identified Doppler parameters that can clearly discriminate between benign and malignant growths, including the blood flow rate in the tumor over $1.85 \mathrm{~cm} / \mathrm{s}(p=0.007)$ and RMI over $0.16(p=0.013)$. The sensitivity and specificity of our diagnostic model are $87 \%$ and $68 \%$, respectively, with a probability threshold of 0.3
\end{abstract}

Keywords: ovarian tumors, risk of malignancy, screening, ultrasound, ovarian tumor echotexture, Doppler ultrasonography, blood flow characteristics

Acknowledgements: the authors thank Komarova MV, Cand. Sci. (Biol.) and Associate Professor at the Samara State Medical University for her invaluable help with statistical analysis

Author contribution: all authors equally contributed to the study at its every stage.

Compliance with ethical standards: the study was approved by the Ethics Committee of Samara State Medical University (Protocol № 194 dated September 12, 2018). Informed consent was obtained from all study participants.

Correspondence should be addressed: Alina A. Demura pr. Maslennikova, 25, Samara, 443056; lina281@ya.ru

Received: 12.02.2020 Accepted: 28.02.2020 Published online: 13.03.2020

DOI: $10.24075 / \mathrm{brsmu} .2020 .016$

\section{УЛЬТРАЗВУКОВЫЕ АСПЕКТЫ И СКРИНИНГ ОПУХОЛЕЙ И ОПУХОЛЕВИДНЫХ ОБРАЗОВАНИЙ ЯИЧНИКОВ У ПАЦИЕНТОК РЕПРОДУКТИВНОГО ВОЗРАСТА}

\author{
Н. В. Спиридонова, А. А. Демура, В. О. Катюшина
}

Самарский государственный медицинский университет, Самара, Россия

Опухоли яичников возникают в любом возрасте, снижают репродуктивный потенциал женщины, имеют высокий риск малигнизации и являются показанием для оперативного лечения. На сегодняшний день продолжается поиск оптимальных алгоритмов скрининга опухолей данной нозологии. Целью работы было оценить прогностическую эффективность ультразвуковых (УЗ) признаков для дифференциальной диагностики злокачественных, доброкачественных и пограничных опухолей яичников у женщин репродуктивного возраста. Обследованы 168 пациенток репродуктивного возраста с опухолевыми и опухолевидными образованиями яичника, прооперированных с 2012 по 2015 г., и сопоставлены морфологические данные верифицированного процесса в яичниках с данными комплексного УЗИ с импульсно-волновым допплеровским режимом. В исследовании не выявлено зависимости размеров и объема образований яичников от морфологической структуры опухоли. Обнаружены эхограсические особенности опухолей яичников: наличие солидного компонента ( $p<0,001)$; наличие перегородок ( $p=0,029)$ и разрастаний по внутренней поверхности капсулы $(p<0,001)$; наличие умеренного и значительного количества свободной жидкости в малом тазу $(p=0,007)$ и бугристая поверхность капсулы образования яичника ( $p=0,008)$. Наличие солидного образования увеличивало вероятность появления злокачественной и пограничной опухолей в 31,69 раза, кистозносолидной структуры образования - в 3,46 раза. Выделены значимые допплерометрические показатели, способные четко обозначить разницу между доброкачественным и злокачественным процессами, а именно превышение скорости кровотока свыше 1,85 cм/с ( $p=0,007)$ и ИР более 0,16 (p = 0,013). Чувствительность и специфичность данной диагностической модели составляют 87\% и 68\% при значении пороговой вероятности 0,3.

Ключевые слова: опухоли яичников, риск малигнизации, скрининг опухолей, ультразвуковое исследование, эхоструктура опухолей яичников, допплерография, особенности кровотока

Благодарности: к. б. н., доценту Самарского университета М. В. Комаровой за помощь в статистической обработке результатов исследования. Вклад авторов: Н. В. Спиридонова, А. А. Демура, В. О. Катюшина - равнозначен на всех этапах работы и написания статьи.

Соблюдение этических стандартов: исследование одобрено этическим комитетом СамГМУ (протокол № 194 от 12 сентября 2018 г.); все участники подписали информированное согласие на участие в исследовании.

$\triangle$ Для корреспонденции: Алина Андреевна Демура пр. Масленникова, д. 25, г. Самара, 443056; lina281@уа.ru

Статья получена: 12.02.2020 Статья принята к печати: 28.02.2020 Опубликована онлайн: 13.03.2020 DOI: $10.24075 /$ vrgmu.2020.016

Ovarian neoplasms are a continuing concern for gynecologists. They can develop at any age, carry a high risk for malignant transformation, reduce the reproductive potential of a woman and are an indication for surgery. The complexity of structural and functional organization of female reproductive glands determines the vast diversity of histological types of ovarian neoplasms, especially in reproductive-age women. Mixed type tumors constituted by at least 2 histological types amplify this diversity even further. Therefore, it is important to identify the sonographic features of ovarian neoplasms that 
can suggest their malignancy [1]. Some authors estimate that epithelial cancer accounts for $60 \%$ of all ovarian neoplasms and $80-90 \%$ of ovarian malignancies [2]. The rest of ovarian tumors arise from germ and stromal cells, are typically found in younger patients and their sonographic appearance can pose diagnostic difficulty for the clinician.

Because ovarian tumors are fast-growing and aggressive, about $60-70 \%$ of patients have advanced stages (III-IV) of the disease at the time of presentation [3]. The use of ultrasonography (US) and the improvement of its diagnostic efficacy may be a solution to the problem of early ovarian cancer detection. US is a noninvasive, cheap, widely available and reproducible modality introduced in 1970 [4-6]. The first ultrasound screening tests were offered to women in the 1980s; they consisted in the transabdominal examination of pelvic organs, which was not the best effective strategy, for anatomical reasons. In 1990, I. Jacobs included transvaginal scans in his screening model. Since then, US has been the primary diagnostic modality for suspected ovarian neoplasms. Over the years, better accuracy in discriminating between malignant and benign tumors has been achieved due to the use of Doppler US. The technique relies on the phenomenon of neovascularization: new capillaries start to develop in the tumor, promoting its further growth. In a malignant tumor, blood flow has a number of characteristics determined by the lack of vascular smooth muscle fibers and the presence of multiple vascular shunts increasing the rate of blood flow in the neoplasm [7].

The aim of this study was to evaluate the prognostic efficacy of some sonographic features in the differential diagnosis of benign and malignant ovarian tumors in reproductive-age women.

\section{METHODS}

The groundwork for this research was laid by the prospective study conducted in 168 reproductive-age women with a morphologically verified ovarian neoplastic process who underwent surgery at Samara Regional Oncology Center in 2012-2015. The following inclusion criteria were applied: age of 18 to 40 years; US findings suggestive of an ovarian mass; subsequent surgery and a histopathological examination of the excised tissue. Exclusion criteria: age below 18 and above 40 years; a medical history of cancer.

Pulsed-wave Doppler scans were performed using a Philips IU-22 scanner (Philips; USA).

The patients were divided into 3 groups according to the WHO classification (2013): 1) 101 (60.1\%) patients with benign tumors; 2) 24 (14.3\%) patients with borderline tumors; 3) 43 (25.6\%) patients with malignant tumors.

The following parameters were evaluated: the size and the volume of the ovarian mass, fluid buildup in the pelvis, the type and the morphologic appearance of the tumor. The neoplastic process was evaluated based on the type of the ovarian mass (solid, cystic, mixed), the involvement of 1 or both ovaries (uni- or bilateral lesions), the size of the lesion, the presence of septations, the presence of projections on the external/internal surface of the capsule and the quality of the capsule surface itself, as well as blood flow in the tumor. We also measured the blood flow velocity in the tumor and the resistive index. Statistical analysis was carried out in SPSS21 (20130626-3; An IBM Company; USA) and Microsoft Excel (Microsoft; USA).

\section{RESULTS}

The maximum size of the tumors (Table 1) varied between $77.26 \pm 6.94 \mathrm{~mm}$ and $97.06 \pm 15.29 \mathrm{~mm}$. No positive correlation was established between the size of the tumor and the stage of the disease. In the patients with benign ovarian tumors, the tumor volume was $99.06 \pm 128.18 \mathrm{ml}$ on average; in the patients with borderline tumors, it was $814.54 \pm 358.32$ $\mathrm{ml}$, and in the patients with malignancies, $579.17 \pm 196.37 \mathrm{ml}$ $(p=0.941)$.

When analyzing the ultrasound appearance of the tumors, we assessed the involvement of one or both ovaries in the neoplastic process. We also identified a group of 15 patients who had undergone adnexa removal emergency surgery at the gynecological departments of general hospitals and had been subsequently referred to specialist centers for a postoperative US examination and a reexamination of histology slices. Unilateral lesions were more often observed in the patients with benign $(81.2 \%)$ and malignant $(86 \%)$ tumors than in the patients with borderline tumors $(54.2 \%)(p=0.006)$.

Based on their echotexture, the tumors were classified into 3 types (Fig. 1): cystic, solid and mixed, with both cystic and solid components $(p<0.001)$. Women with cystic ovarian masses made up $72.6 \%$ of the study participants. In this group of patients, the masses were round in shape, with wellcircumscribed smooth margins, anechoic, with single or multiple septa and without projections along the internal capsule. Cystic masses were more typical to the patients with benign tumors (87.1\%), compared to the women who had borderline (54.2\%) and malignant (48.8\%) tumors, respectively.

Patients with mixed type tumors (with both cystic and solid components) made up $22.6 \%$ of all study participants. In this group, the tumors were round-shaped, with fairly well-defined smooth margins, anechoic, with septations or areas of echogenicity and a solid irregular or regular-shaped component. The mixed type was more prevalent in the patients with borderline and malignant tumors (37.5 and 39.5\%, respectively) than in the women with benign tumors (11.9\%).

Solid tumors were observed in $4.8 \%$ of the patients. Tumors of this type were either round or irregular in shape, with fairly well-defined angular margins; they were characterized by mixed echogenicity or the presence of single anechoic round-shaped components. The solid type was observed in the participants with malignancies (11.6\%).

We also evaluated the surface of the tumor capsule (Fig. 2), which was either smooth or nodular $(p=0.008)$. In the patients with benign tumors, the capsule surface was smooth in $80(79.2 \%)$ cases and nodular in 21 (20.8\%) cases. In the group

Table 1. Sizes of ovarian tumors

\begin{tabular}{|c|c|c|c|c|c|c|c|}
\hline & Benign & Borderline & Malignant & $p_{1-2}$ & $p_{1-3}$ & $p_{2-3}$ & $p$ \\
\hline Size 1 & $88.10 \pm 4.90$ & $97.06 \pm 15.29$ & $91.87 \pm 7.42$ & 0.867 & 0.431 & 0.643 & 0.724 \\
\hline Size 2 & $77.48 \pm 4.47$ & $82.56 \pm 14.00$ & $77.26 \pm 6.94$ & 0.886 & 0.981 & 0.817 & 0.983 \\
\hline Size 3 & $82.79 \pm 4.59$ & $89.81 \pm 14.52$ & $84.56 \pm 6.94$ & 0.972 & 0.669 & 0.783 & 0.909 \\
\hline Tumor volume, $\mathrm{ml}$ & $599.06 \pm 128.18$ & $814.54 \pm 358.32$ & $579.17 \pm 196.37$ & 0.965 & 0.727 & 0.844 & 0.941 \\
\hline
\end{tabular}

Note: $p_{1-2}, p_{1-3}, p_{2-3}$ - intergroup comparison; $p$ - the Kruskal-Wallis $\mathrm{H}$ test. 
of patients with borderline tumors, smooth capsule surface was observed in 17 (70.8\%) cases, whereas nodular, in 7 (29.2\%) women. In the group of patients with malignant tumors, the capsule surface was smooth in $23(53.5 \%)$ patients, whereas nodular, in $20(46.5 \%)$ patients. Additionally, we looked at the presence of projections on the external $(p=0.192)$ and internal $(p<0.001)$ surfaces of the capsule. We found that $40.6 \%$ of patients with benign tumors had projections on the external surface and $4 \%$ of women, on the internal surface. In the group of patients with borderline tumors, no projections were observed on the external surface of the capsule, and $79.2 \%$ had projections on the internal surface. In the groups of patients with malignant tumors, $65.1 \%$ had projections on the external surface, whereas $9.3 \%$, on the internal surface.

Small amounts of free pelvic fluid were observed in $15.8 \%$ of women with benign tumors. In this group, there were no patients with moderate or large amounts of free fluid in the pelvis. In the borderline group, fluid buildup was observed in every third patient (33.3\%), of whom $16.7 \%$ had it in moderate and large volumes. However, free pelvic fluid was discovered only in $14 \%$ of women with malignancies; of them only $1 \%$ (2.3\%) had in large quantities (Kruskal-Wallis $\mathrm{H}$ test, $p=0.007$ ).

Doppler ultrasonography can estimate blood flow in the tumor. This facilitates timely diagnosis of a neoplastic process in the ovaries and is especially important for deciding on the treatment strategy in reproductive-age women. In our study, blood flow parameters were evaluated in several steps.

Step I. The presence of blood flow within the tumor was evaluated in all patient groups $(p<0.001)$. Tumor blood flow was detected by Doppler ultrasonography in $18(17.8 \%)$ patients with benign tumors; another 27 (26.7\%) patients with benign tumors had single colored spots on the dopplergram (power Doppler). In the group of patients with borderline tumors, blood flow was registered in 9 (37.5\%) women; another 9 (37.5\%) had single colored spots on the dopplergram (power Doppler). Of all patients with malignancies, blood flow was detected in 23 (53.5\%) women, whereas single colored spots, in 15 (34.9\%) women (power Doppler).

Step II. Tumor blood flow rate and resistive index (RI) were measured (Table 2). In the patients with benign tumors, the average blood flow rate was $1.45 \pm 0.4 \mathrm{~cm} / \mathrm{s}$ and the $\mathrm{RI}$ value was the lowest. For those with borderline tumors, the average blood flow rate was $4.58 \pm 1.44 \mathrm{~cm} / \mathrm{s}$ and the $R$ I value was $0.21 \pm 0.05$. In the patients with malignancies, the maximum values for blood flow rate and RI were $6.34 \pm 1.17 \mathrm{~cm} / \mathrm{s}$ and $0.26 \pm 0.04$, respectively. We were able to identified Doppler parameters that helped us to discriminate between benign and malignant tumors: tumor blood flow rate over $1.85 \mathrm{~cm} / \mathrm{s}$ $(p=0.007)$ and $\mathrm{Rl}$ over $0.16(p=0.013)$.

Using stepwise logistic regression, the US findings and the calculated blood flow rate values, we built a model for early diagnosis of ovarian cancer (Table 3). The type of tumor composition was a significant predictor: solid masses were at increased (31.69fold) risk for malignant or borderline transformation; a mixed type with cystic and solid components increased such risk 3.46-fold. Sensitivity and specificity of this diagnostic model were 87 and $68 \%$, respectively, with a probability threshold of 0.3 .

\section{DISCUSSION}

Considering the morphologic diversity of ovarian growths and their frequently poor outcomes, the search for early

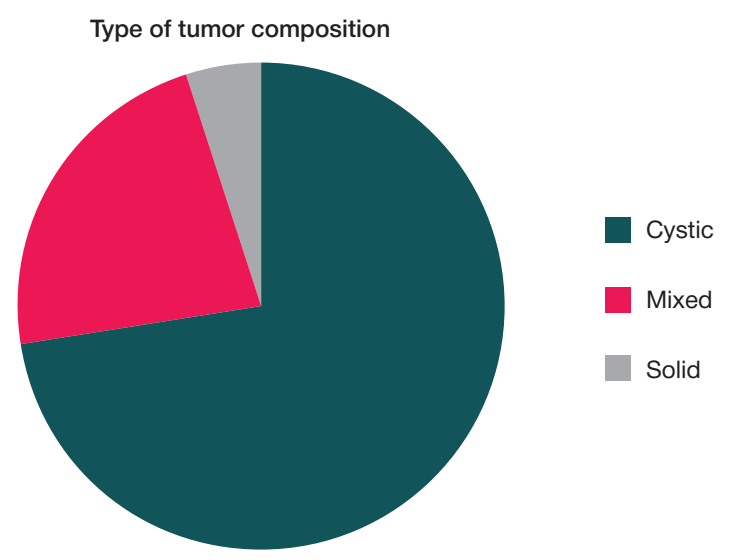

Fig. 1. The composition of tumors determined by ultrasonography

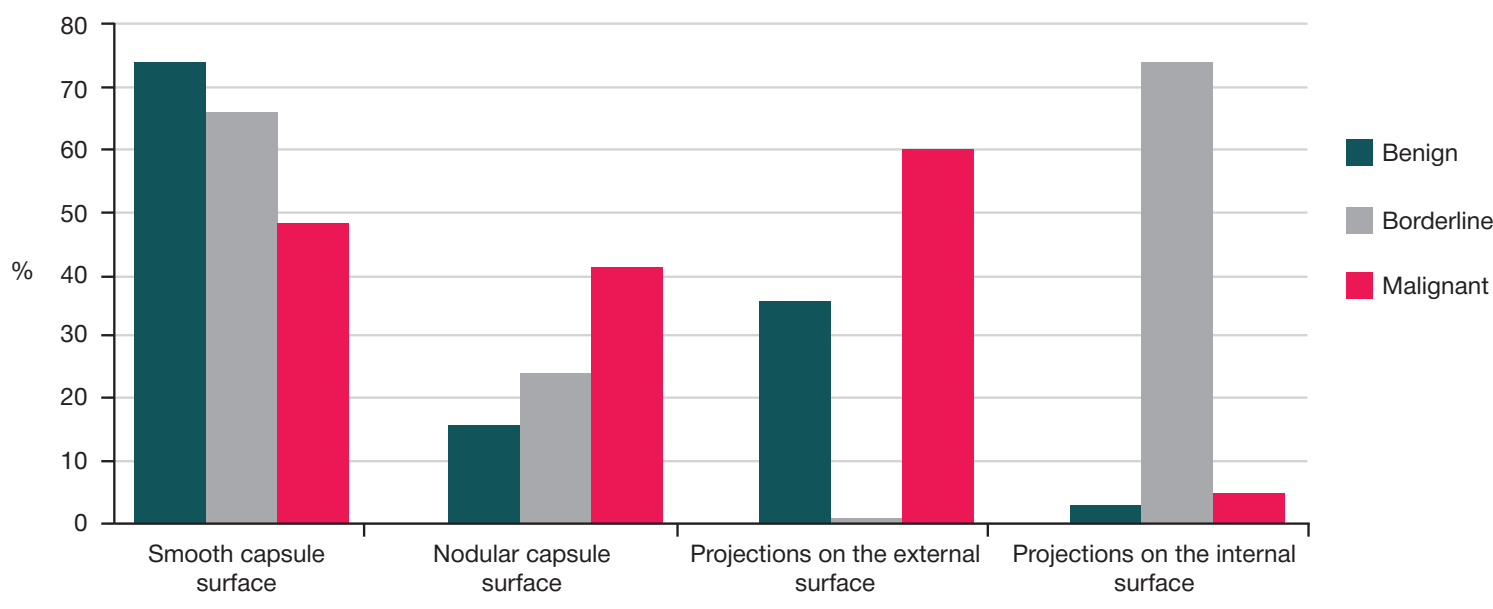

Fig. 2. Ovarian tumor capsule surface in reproductive-age patients 
Table 2. Characteristics of blood flow in ovarian tumors

\begin{tabular}{|l|c|c|c|c|c|c|c|}
\hline & Benign & Borderline & Malignant & $p_{1-2}$ & $p_{1-3}$ & $p_{2-3}$ & $p$ \\
\hline$v, \mathrm{~cm} / \mathrm{s}$ & $1.45 \pm 0.40$ & $4.58 \pm 1.44$ & $6.34 \pm 1.17$ & 0.007 & $<0.001$ & 0.261 & $<0.001$ \\
\hline $\mathrm{RI}$ & $0.08 \pm 0.02$ & $0.21 \pm 0.05$ & $0.26 \pm 0.04$ & 0.013 & $<0.001$ & 0.319 & $<0.001$ \\
\hline
\end{tabular}

Note: $v$ is blood flow rate in the ovarian tumor, expressed as $\mathrm{cm} / \mathrm{s}$; $\mathrm{Rl}$ is resistive index: $p_{1-2}, p_{1-3}, p_{2-3}$ show intergroup differences; $\mathrm{p}$ is the result of the Kruskal-Wallis $\mathrm{H}$ test.

predictors of malignancy in reproductive-age women remains a pressing concern. Algorithms predicting the risk of malignant transformation are in continuing development, aiming at detecting cancer in its early stages and thus reducing the extent of surgery. In 1996, the risk-of-malignancy index (RMI) was first proposed. It was designed to estimate the risk of malignant transformation using a scoring system [8]. Similar to our model, it relied on US features, such the presence of septations and solid components, the involvement of 1 or both ovaries and ascites. However, unlike our model, the index also accounted for the presence of abdominal metastases, the menopausal status (premenopause/postmenopause) and the absolute values of CA 125. For the sake of convenience, each component was attributed a value (score) and the following formula was applied to calculate the index: $\mathrm{RMI}=$ Ultrasound features (score) . Menopausal status (premenopause/ postmenopause) - Absolute values of CA 125. If the resulting $\mathrm{RMI}$ was below 200, the ovarian mass was assumed to be potentially benign.

The International Ovarian Tumor Analysis (IOTA) carried out in 1999-2000 aimed at formulating the guidelines and creating the models for characterizing ovarian tumors [9]. The models were developed for use by clinicians regardless of their qualifications and allowed them to better understand the etiology of ovarian cancer and the role of CA 125 and other cancer biomarkers. Later, an international team of researchers proposed 2 logistic regression models: LR1 and LR2 for differentiating between benign and malignant ovarian growths $[10,11]$. According to the models, the sonographer should evaluate over 40 different clinical and US variables. The sensitivity and accuracy of the method were 96\% and $90 \%$, respectively, but the method turned to be very timeconsuming and generally demanding; it did not account for the patient's medical history and laboratory test results. The researchers concluded that recognition of US features typical to an ovarian pathology by an experienced sonographer is the best method to characterize this pathology and that CA 125 does not improve the diagnostic accuracy in predicting the malignancy of the tumor [12-14]. Using statistical analysis, we were able to reduce the number of variables and thus to save time for and simplify the subsequent calculations without reducing the sensitivity and specificity of our diagnostic model (87 and 68\%).

In 2011, it was demonstrated that the algorithms relying on a combination of two tumor markers (CA 125 and HE 4) and
US findings should be used to identify women with indications for surgery, who should be referred to cancer centers [15].

In 2011, the international NICE clinical guideline CG 122 on the management of patients with ovarian cancer emphasized the necessity of using RMI, which accounts for 3 preoperative parameters, just like the algorithm proposed in 1996 [16]: serum CA 125, the menopausal status (M) and ultrasonography score $(U)$. According to the guideline, US findings should be scored 1 point for each of the following characteristics: multiocular cysts, solid areas, metastases, ascites, bilateral lesions. The menopausal status should be evaluated in the following way: premenopausal women score 1 point; postmenopausal, 3 points (postmenopausal females are defined as those who have not had periods for over a year or who are older than 50 and have undergone hysterectomy). Serum CA 125 is expressed in $\mathrm{IU} / \mathrm{ml}$. Its values can vary between 0 and a few hundreds or even thousands of units. RMI is, thus, calculated using the formula: $\mathrm{RMI}=\mathrm{U} \cdot \mathrm{M} \cdot \mathrm{CA}$ 125; if $\mathrm{RMI}$ value is above 200 , the patient should be recommended additional tests.

Today, it is often reported in the literature that no significant differences can be established between benign and malignant ovarian tumors using the classic criteria for malignancy, such as irregular shape, irregular margin or large size of the tumor.

\section{CONCLUSIONS}

This study has not established a correlation between the size and volume of ovarian tumors and their morphological structure. However, the analysis of tumor echotexture allowed us to identify US characteristics associated with malignancy, including the presence of a solid component $(p<0.001)$, septations ( $p=0.029)$ and projections on the internal surface of the tumor capsule $(p<0.001)$, moderate or significant buildup of free fluid in the small pelvis $(p=0.007)$ and the nodular surface quality of the tumor capsule $(p=0.008)$.

The study demonstrates that blood flow in the tumor could be a sign of possible malignant transformation $(p<0.001)$. For reproductive-age women, Doppler parameters have been identified that can clearly discriminate between benign and malignant growths: the blood flow rate over $1.85 \mathrm{~cm} / \mathrm{s}(p=0.007)$ and $\mathrm{RI}$ over $0.16(p=0.013)$.

The identified US features (a solid or a mixed type mass, blood flow in the tumor and increased resistance index) can be used as key parameters in differentiating between various types of ovarian tumors.

Table 3. The model for early diagnosis of ovarian cancer in reproductive-age patients

\begin{tabular}{|c|c|c|c|c|}
\hline Risk factor & Risk factor grading & Regression coefficient, $b$ & OR $(95 \% \mathrm{Cl})$ & $p$ \\
\hline \multirow{3}{*}{ Composition type } & Cystic, reference & 0 & 1 & - \\
\hline & Solid & 3.46 & $31.69(3.16-318.11)$ & 0.003 \\
\hline & Mixed & 1.23 & $3.40(1.32-8.77)$ & 0.011 \\
\hline Blood flow in the tumor & "Yes" in comparison with "no" & 0.98 & $2.68(1.56-4.58)$ & $<0.001$ \\
\hline $\mathrm{RI}$ & Increment by 1 & 2.23 & $9.34(1.92-45.49)$ & 0.006 \\
\hline Constant & - & -2.35 & - & $<0.001$ \\
\hline
\end{tabular}


1. Ashrafyan LA, Babaeva NA, Antonova IB, Ivashina SV, Lustik AV, Alyoshikova Ol, et al. Ultrasound criteria for early diagnosis of ovarian cancer. Tumors of the female reproductive system. 2015; 11 (1): 53-60. Russian.

2. Urmancheeva AF, Kutusheva GF, Ulrih EA. Opuholi jaichnika (klinika, diagnostika, lechenie). Posobie dlja vrachej. SPb.: OOO «Izdatel'stvo N-L», 2012; 68 s. Russian.

3. Maksimov SYa, Khadzhimba AV, Vyshinskaya EA, Sobolev IV, Ilyin AA. Rak organov reproduktivnoj sistemy v molodom vozraste. Prakticheskaja onkologija. 2017; 18 (2): 185-96. Russian.

4. Bulanov MN. UI'trazvukovaja ginekologija. V 3-h tomah. T. 2. M.: Vidar, 2010; 306 s.

5. Manegold-Brauer G, Bellin AK, Tercanli S, Lapaire O, HeinzelmannSchwarz V. The special role of ultrasound for screening, staging and surveillance of malignant ovarian tumors: distinction from other methods of diagnostic imaging. Arch Gynecol Obstet. 2012; (289): 491-8.

6. Levine D, Brown DL, Andreotti RF, Benacerraf B, Benson CB, Brewster WR, et al. Management of asymptomatic ovarian and other adnexal cysts imaged at US: society of radiologists in ultrasound consensus conference statement. Radiology. 2010; 256 (3): 943-54.

7. Hachkuruzov SG. UI'trazvukovaja simptomatika i differencial'naja diagnostika kist i opuholej jaichnikov. M.: MEDpress-inform, 2014; 288 s. Russian.

8. Gasparov AS, Zhordania KI, Payanidi YuG, Dubinskaya ED. Oncogynecological aspects of ovarian cysts. Bulletin of the RAMS. 2013; 68 (8): 9-13. Russian.

9. Higgins RV, Matkins JF, Marroum MC. Comprasion of fine-

\section{Литература}

1. Ашрафян Л. А., Бабаева Н. А., Антонова И. Б., Ивашина С. В., Люстик А. В., Алешикова О. И. и др. Ультразвуковые критерии ранней диагностики рака яичников. Опухоли женской репродуктивной системы. 2015; 11 (1): 53-60.

2. Урманчеева А. Ф., Кутушева Г. Ф., Ульрих Е. А. Опухоли яичника (клиника, диагностика, лечение). Пособие для врачей. СПб.: ООО «Издательство Н-Л», 2012; 68 с.

3. Максимов С. Я., Хаджимба А. В., Вышинская Е. А., Соболев И. В., Ильин А. А. Рак органов репродуктивной системы в молодом возрасте. Практическая онкология. 2017; 18 (2): 185-96.

4. Буланов М. Н. Ультразвуковая гинекология. В 3-х томах. Т. 2. М.: Видар, 2010; 306 с.

5. Manegold-Brauer G, Bellin AK, Tercanli S, Lapaire O, HeinzelmannSchwarz V. The special role of ultrasound for screening, staging and surveillance of malignant ovarian tumors: distinction from other methods of diagnostic imaging. Arch Gynecol Obstet. 2012; (289): 491-8.

6. Levine D, Brown DL, Andreotti RF, Benacerraf B, Benson CB, Brewster WR, et al. Management of asymptomatic ovarian and other adnexal cysts imaged at US: society of radiologists in ultrasound consensus conference statement. Radiology. 2010; 256 (3): 943-54.

7. Хачкурузов С. Г. Ультразвуковая симптоматика и дифференциальная диагностика кист и опухолей яичников. М.: МЕДпресс-информ, 2014; 288 с.

8. Гаспаров А. С, Жорданиа К. И., Паяниди Ю. Г., Дубинская Е. Д. Онкогинекологические аспекты кистозных образований яичников. Вестник Российской академии медицинских наук. 2013; 68 (8): 9-13. needle aspiracion cytologic findings of ovarian cysts with ovarian histologic findings. Am J Obstet gynecol. 1999; 180 (3): 550-3.

10. Campbell S. Ovarian cancer: role of ultrasound in preoperative diagnosis and population screening. Ultrasound Obstet Gynecol. 2012; (40): 245-54.

11. Kaijser J, Bourne T, Valentin L, Sayasneh A, Van Holsbeke C, Vergote I, et al. Improving strategies for diagnosing ovarian cancer: a summary of the International Ovarian Tumor Analysis (IOTA) studies. Ultrasound Obstet Gynecol. 2013; 41 (1): 9-20.

12. Fischerova D. Ultrasound scanning of the and abdomen for staging of gynecological tumors: a review. Ultrasound Obstetrics Gynecol. 2011; (38): 246-66.

13. Van Gorp T, Cadron I, Despierre E, Daemen A, Leunen K., Amant F, et al. HE 4 and CA 125 as a diagnostic test in ovarian cancer: prospective validation of Risk of Ovarian Malignancy Algorithm. $\mathrm{Br}$ J Cancer. 2011. (104): 863-70.

14. Valentin L, Ameye L, Franchi D, Guerriero S, Jurkovic D, Savelli L, et al. Risk of malignancy in unilocular cysts: a study of 1148 adnexal masses classified as unilocular cysts at transvaginal ultrasound and review of the literature. Ultrasound Obstet Gynecol. 2013; 41 (1): 80-89.

15. Escudero JM, Auge JM, Filella X, Torne A, Pahisa J, Molina R. Comparison of serum human epididymis protein 4 with cancer antigen 125 as a tumor marker in patients with malignant and nonmalignant diseases. Clin Chem. 2011; (57): 1534-44.

16. Ovarian cancer: recognition and initial management (CG122). National institute for health and care excellence. Clinical guideline. 2011, p. 19. Available from: https://www.nice.org.uk/terms-andconditions\#notice-of-rights.

9. Higgins RV, Matkins JF, Marroum MC. Comprasion of fineneedle aspiracion cytologic findings of ovarian cysts with ovarian histologic findings. Am J Obstet gynecol. 1999; 180 (3): 550-3.

10. Campbell S. Ovarian cancer: role of ultrasound in preoperative diagnosis and population screening. Ultrasound Obstet Gynecol. 2012; (40): 245-54.

11. Kaijser J, Bourne T, Valentin L, Sayasneh A, Van Holsbeke C, Vergote I., et al. Improving strategies for diagnosing ovarian cancer: a summary of the International Ovarian Tumor Analysis (IOTA) studies. Ultrasound Obstet Gynecol. 2013; 41 (1): 9-20.

12. Fischerova D. Ultrasound scanning of the and abdomen for staging of gynecological tumors: a review. Ultrasound Obstetrics Gynecol. 2011; (38): 246-66.

13. Van Gorp T, Cadron I, Despierre E, Daemen A, Leunen K., Amant F, et al. HE 4 and CA 125 as a diagnostic test in ovarian cancer: prospective validation of Risk of Ovarian Malignancy Algorithm. $\mathrm{Br}$ J Cancer. 2011. (104): 863-70.

14. Valentin L, Ameye L, Franchi D, Guerriero S, Jurkovic D, Savelli L, et al. Risk of malignancy in unilocular cysts: a study of 1148 adnexal masses classified as unilocular cysts at transvaginal ultrasound and review of the literature. Ultrasound Obstet Gynecol. 2013; 41 (1): 80-89.

15. Escudero JM, Auge JM, Filella X, Torne A, Pahisa J, Molina R. Comparison of serum human epididymis protein 4 with cancer antigen 125 as a tumor marker in patients with malignant and nonmalignant diseases. Clin Chem. 2011; (57): 1534-44.

16. Ovarian cancer: recognition and initial management (CG122). National institute for health and care excellence. Clinical guideline. 2011, p. 19. Available from: https://www.nice.org.uk/terms-andconditions\#notice-of-rights. 